Article

\title{
Anti-Proliferative and Apoptotic Induction Effect of Elateriospermum Extract on Human Lung Cancer Cell Line A549 +
}

\author{
Siroshini K Thiagarajan ${ }^{1}$, Kokila Vani Perumal ${ }^{1}$, Nurul Husna Shafie ${ }^{2}$, Khairul Kamilah Abdul \\ Kadir ${ }^{3}$ and Hasnah Bahari ${ }^{1, *}$ \\ 1 Department of Human Anatomy, Faculty of Medicine and Health Science, Universiti Putra Malaysia, \\ Serdang 43400, Selangor, Malaysia; t.siroshini@gmail.com (S.K.T.); kokilavaniperumal@gmail.com (K.V.P.) \\ 2 Department of Nutrition and Dietetics, Faculty of Medicine and Health Science, Universiti Putra Malaysia, \\ Serdang 43400, Selangor, Malaysia; nhusnashafie@upm.edu.my \\ 3 Innovation and Commercialization Department, Forest Research Institute Malaysia, Kepong 52109, \\ Selangor, Malaysia; nhusnashafie@upm.edu.my \\ * Correspondence: haba@upm.edu.my \\ + Presented at the The 1st International Electronic Conference on Nutrients - Nutritional and Microbiota \\ Effects on Chronic Disease, 2-15 November 2020; Available online: https://iecn2020.sciforum.net/.
}

Published: 30 October 2020

\begin{abstract}
Natural products derived from plants are used to treat cancer due to fewer side effects compared to standard treatments available for cancer. The second highest cancer that causes death worldwide is lung cancer. Therefore, this study aimed to determine the cytotoxic activity of hot and cold aqueous extract of E. tapos seed and shell on human cancer cell line A549 as well as the apoptosis mechanism. The apoptosis mechanisms were evaluated by cell viability (MTT assay), Hoechst 33358 staining and detection of reactive oxygen species (ROS) activity. The apoptosis inducing activity was analyzed in set of morphological and biochemical features. Hot aqueous shell extract (SHH) showed an anti-proliferative effect at the IC 50 $_{50}$ of $49.8 \pm 0.06 \mu \mathrm{g} / \mathrm{mL}$ correlated with apoptosis induction by increasing the ROS activity by significant $(p<0.05)$ increase of 3.25 folds compared to control. Results suggest that SHH poses an anti-proliferative effect on account of apoptosis through ROS mediated mitochondria mutilation.
\end{abstract}

Keywords: Elateriospermum tapos; lung cancer; apoptosis

\section{Introduction}

Elateriospermum tapos (E. tapos) comes from the Euphorbiaceace family, commonly known as "perah" or "pogoh" nut in Malay, is a large buttresses tree found in primary and secondary forests, mixed dipterocarp forests and forest edges. In Malaysia, this species can be found in Jengka Forest Reserve, Peninsular Malaysia [1]. E. tapos is not classified as a major medicinal as of today. Nonetheless being a tree of ornamental value [2], the different parts of the plant have been used in folk medicine. The white and sticky latex were used in treating cracked soles of the foot [3].

E.tapos has been reported to have phytochemicals such as flavonoid, tannin, alkaloid that hold therapeutic properties against many diseases. The daily consumption of flavonoids has properties that reduced the risk of cancer [4]. Plant-derived products are widely used as traditional medicine due to less toxic and fewer side effects [5]. Sita, Thanaset, Prasan, \& Auamporn (2018) has stated that the compound, taraxerane triterpenes found in E. tapos was effective against lung cancer (NCI-H187) and breast cancer cell lines and also has evidence in vitro study as an anti-mycobacterial against Mycobacterium tuberculosis [6]. Further pharmacological research has revealed several biological 
activities such as antioxidant, antitumor and antimycobacterial [7]. These activities were ascribed by various chemical constituents such as taraxane, triterpenes, flavonoids, acetates and palmitates $[6,7]$.

Lung cancer is the second highest cancer that cause of death globally after breast cancer $[8,9]$. The statistics showed in the year 2012 that, 1.8 million new cases every year and the mortality rate is 1.6 million worldwide [9]. The standard treatments that available for cancer are chemotherapy, radiotherapy, tumor removal via surgery, and immunotherapy [10]. Unfortunately, it associated with side effects such as nausea, fatigue, appetite loss, and edema. Besides, the 5 year survival rate still unsatisfied with lung cancer patients [11].

Malaysia, with broad spectrum of natural biodiversity has been indicated to have more than 6000 to 7000 species higher plant that have therapeutic or medicinal properties. Based on that fact, it is an excellent opportunity if we could also utilized the waste part that beneficial to our health which would contribute to economic enhancement. Therefore, bringing to the objective of this study to determine the cytotoxic activity of hot and cold aqueous of E. tapos seed and shell on human cancer cell line A549 and focus on the apoptosis mechanism.

\section{Materials and Methods}

\subsection{Sample Preparation}

The samples were washed and separated to dry in the oven at $40{ }^{\circ} \mathrm{C}$ for 3 days. Thereafter, the fine powder was obtained from the ground dried samples by using a fine mesh sieve. The fresh samples were kept at $-20^{\circ} \mathrm{C}$ prior to extraction.

\subsection{Hot and Cold Water Extraction}

Decoction method was used to prepare the aqueous extract of samples. For hot water extraction, $100 \mathrm{~g}$ of the dried powdered samples were soaked in $1 \mathrm{~L}$ of water at $70^{\circ} \mathrm{C}$ for $12 \mathrm{~h}$, while the cold water extraction was left for 2 days at room temperature. The samples were filtered using a Whatman filter paper No.1. Thereafter, the samples were freeze-dried and stored at $-20^{\circ} \mathrm{C}$.

\subsection{Cells, Reagent, and Antibodies}

Human cancer cell line A549 was obtained from ATCC (American Type Culture Collection). The cells were grown in RPMI 1640 medium with 10\% FBS (fetal bovine serum) and antibiotic (1\% penicillin-streptomycin) at $37^{\circ} \mathrm{C}$ in the humidified atmosphere with $5 \% \mathrm{CO}_{2}$ [12].

\subsection{Cell Viability Assay}

Cell viability was evaluated by using MTT assay. The cells were plated $1.0 \times 10^{4}$ cells/well into the 96-well flat bottom plate and incubated for 24,48 , and $72 \mathrm{~h}$ in $5 \%$ of $\mathrm{CO}_{2}$ incubator at $37^{\circ} \mathrm{C}$. After 24,48 and $72 \mathrm{~h}$ of incubation, $20 \mu \mathrm{l}$ of MTT reagent $(5 \mathrm{mg} / \mathrm{mL})$ was added to each well for $4 \mathrm{~h}$ and the absorbance was read at $550 \mathrm{~nm}$ using a microplate reader. The inhibitory concentration $\mathrm{IC}_{50}$, were obtained and tabulated [12].

\subsection{Analysis of Apoptosis by Hoechst 33358}

Hoechst 33358 staining was used to analyze the morphology of apoptosis cells. The cells were plated at $1.0 \times 10^{6}$ cells per well in a 6-well plate until reaches confluent. Cells were exposed at the IC 50 of all the extracts for $24 \mathrm{~h}$. After $24 \mathrm{~h}$, the cells were washed twice with cold PBS (phosphate buffer saline), then fixed with cold methanol and acetic acid 3:1 (v/v) for half an hour in dark, followed by the observation under a fluorescence microscope (Microscope, Olympus DX51; Camera, Olympus DP72) [12].

\subsection{Detection of Intracellular Reactive Oxygen Species (ROS)}

Intracellular Reactive oxygen species (ROS) was analyzed using a ROS assay kit. Cells were plated at $2.5 \times 10^{3}$ cells/well in a black 96-well plate. Cells were treated with IC 50 of all the extracts for 
$24 \mathrm{~h}$. Thereafter, it was incubated with DCFH-DA (Dichloro-dihydro-fluorescein diacetate) $(5 \mu \mathrm{M})$ at $37^{\circ} \mathrm{C}$ for half an hour and exposed to $\mathrm{H}_{2} \mathrm{O}_{2}(0.5 \mathrm{mM})$ diluted in culture medium for $1 \mathrm{~h}$. After $1 \mathrm{~h}$, the fluorescence of the cells was measured at $480 \mathrm{~nm} / 520 \mathrm{~nm}$ (EnSpire Multimode Plate Reader, PerkinElmer) [12].

\section{Results}

\subsection{Inhibitory Effects of E. tapos Extracts on A549 Cell Line}

The cells were incubated for $24 \mathrm{~h}$ with different concentrations $(1000 \mu \mathrm{g} / \mathrm{mL}, 800 \mu \mathrm{g} / \mathrm{mL}, 600$ $\mu \mathrm{g} / \mathrm{mL}, 400 \mu \mathrm{g} / \mathrm{mL}, 200 \mu \mathrm{g} / \mathrm{mL}, 100 \mu \mathrm{g} / \mathrm{mL}$ ). Cell viability was determined by using MTT assay. As shown in Table 1, the lowest IC 50 showed was E. tapos seed cold aqueous (SDC) $(28.6 \pm 0.18 \mu \mathrm{g} / \mathrm{mL}$ ), followed by E. tapos seed hot aqueous (SDH) $(45.8 \pm 0.15 \mu \mathrm{g} / \mathrm{mL})$, E. tapos shell hot aqueous (SHH) $(49.8 \pm 0.06 \mu \mathrm{g} / \mathrm{mL})$ and the highest $\mathrm{IC}_{50}$ showed in E. tapos shell cold aqueous (SHC) $(75.9 \pm 0.19$ $\mu \mathrm{g} / \mathrm{mL}$ ). As a positive control (PC), Cisplatin was used that showed IC $_{50}(17.3 \pm 0.01 \mu \mathrm{g} / \mathrm{mL})$. In addition, these extracts have shown less toxic effects against the normal cell lines, MRC5 (IC 50: $>500$ $\mu \mathrm{g} / \mathrm{mL}$; Table 1).

Table 1. Inhibitory concentration IC 50 of E. tapos extracts and Cisplatin on A549 and MRC5 cells after $24 \mathrm{~h}$ of incubation.

\begin{tabular}{lllll}
\hline & & & & \\
E.tapos & Solvents & $\begin{array}{l}\text { Cancer cell line A549 } \\
(\mu \mathrm{g} / \mathrm{mL})\end{array}$ & $\begin{array}{l}\text { Normal cell line } \\
\text { MRC5 }(\mu \mathrm{g} / \mathrm{mL})\end{array}$ \\
\hline Plant extracts & Seed (SD) & Hot Aqueous (H) & $45.8 \pm 0.15$ & $>500$ \\
& Shell (SH) & Hot Aqueous (H) & $49.8 \pm 0.06$ & $>500$ \\
& & Cold Aqueous (C) & $75.9 \pm 0.19$ & $>500$ \\
Standard drug & Cisplatin & & $17.3 \pm 0.01$ & $13.2 \pm 0.05$ \\
\hline
\end{tabular}

\subsection{Effects of E. tapos Extracts on Hoechst 33358 Staining}

The morphological changes of nucleus were identified by the fluorescence microscope. The arrows indicated apoptotic cells (Figure 1). The apoptotic cells are recognized by the high fluorescent condensed chromatin. SDH, SDC, Cisplatin showed condensed and small nuclei as compared to $\mathrm{SHH}, \mathrm{SHC}$, control that has normal nuclei.

\subsection{The Effects E. tapos Extracts on ROS on Treated A549 Cell Line}

ROS decreases the cell viability with an increase in ROS production that results in cell death. As shown in Figure 2, ROS produced by cisplatin treated cells increased by 1.03 fold as compared to control. However, SDH showed the highest (1.4 fold) ROS released as compared to Cisplatin. SHC has the lowest ( 0.94 fold) ROS, followed by, SDC (0.99 fold) and SHH (1.04 fold) as compared to control. 


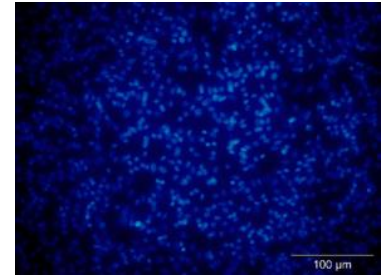

$S D H$

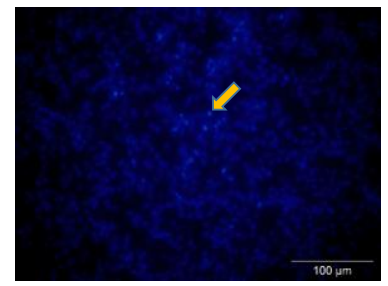

SHH

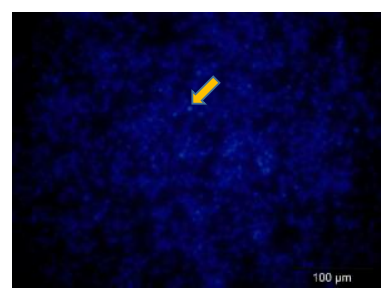

Cisplatin

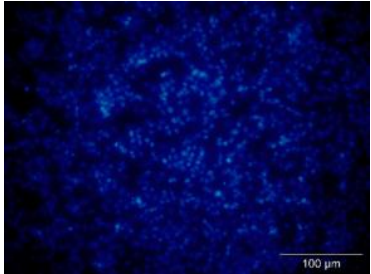

$S D C$

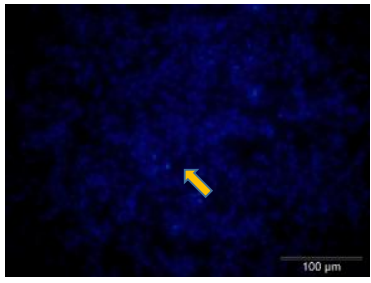

SHC

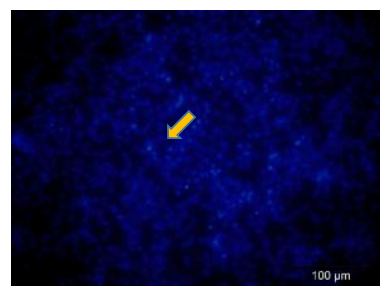

Control

Figure 1. Cell apoptosis morphology observation by Hoechst staining. SDH- Seed Hot Aqueous, SDCSeed Cold Aqueous, SHH- Shell Hot Aqueous, SHC- Shell Cold Aqueous, Cisplatin, ControlUntreated cells.

\section{Reactive Oxygen Species (ROS) released by treated A549}

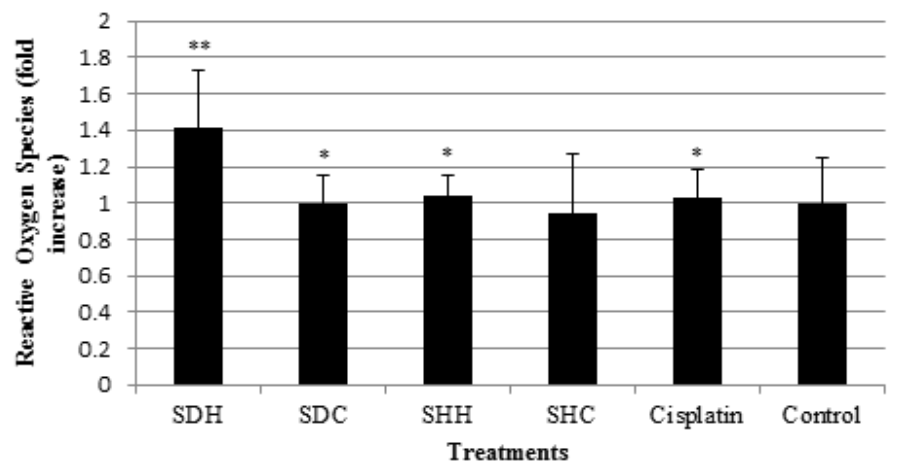

Figure 2. Fold increment of Reactive Oxygen Species (ROS) released from treated A549 cells. Error bar indicates the standard error of the mean of three independent experiments. SDH- Seed Hot Aqueous, SDC- Seed Cold Aqueous, SHH- Shell Hot Aqueous, SHC- Shell Cold Aqueous, CisplatinPositive control, Control-Untreated cells. ${ }^{*} p<0.05,{ }^{* *} p<0.01$ vs control. 


\section{Discussion}

Globally, various plants have been used to treat many diseases, especially in undeveloped countries. As previously stated, natural products such as plants used due to less toxicity. E. tapos has been used for obesity, anti-hyperlipidemia, and cancer research. It is commonly known as perah that consumed either in a cooked or fermented way by the people in local villagers in Southern Thailand [13]. In present work, we demonstrated that determine the cytotoxic activity of E. tapos seed and shell extracts on human cancer cell line A549 and focus on apoptosis mechanism. Cisplatin is a chemotherapeutic drug that was used as a positive control.

The cytotoxic effect of extracts on A549 cells was determined by using MTT assay. Based on Table 1, Cisplatin revealed the lowest IC 50 which is $17.3 \pm 0.01 \mu \mathrm{g} / \mathrm{mL}$, indicating it has the highest inhibition towards A549 at a low concentration. The lowest IC 50 showed among E. tapos treated group was SDC $(28.6 \pm 0.18 \mu \mathrm{g} / \mathrm{mL})$, followed by SDH $(45.8 \pm 0.15 \mu \mathrm{g} / \mathrm{mL}), \mathrm{SHH}(49.8 \pm 0.06 \mu \mathrm{g} / \mathrm{mL})$ and the highest IC 50 showed in SHC $(75.9 \pm 0.19 \mu \mathrm{g} / \mathrm{mL})$. As comparison to the seed skin ethanol extract by Sita, Thanaset, Prasan, \& Auamporn (2018) the IC50 of all samples were within the range of 13.26 to $87.94 \mu \mathrm{g} / \mathrm{mL}$ [6]. This indicates that the killing effect of E.tapos samples are in range in the same period of incubation.

In order to further analyze the mechanism of A549 cell death, Hoechst 33358 was used to observe morphological changes on the DNA of the cells. Cell death is easily visible by the chromatin condensation and fragmentation of the DNA, when compared to the even, flat disc-like in nonapoptotic chromatin. Moreover, dead cell also presents uneven morphology which comprises of a cluster of comparatively bright fragments of condensed DNA. Similarly reported in the study by Thiagarajan et al., 2019, the features observed reflecting on traits seen during the early stage of apoptosis [12].

Confirming on the morphological features of the cells, ROS signaling were studied as the increase in ROS can be due to several events which includes the alteration of mitochondrial lipids. This suggests that the increase in ROS signaling is vital in cell disruption causing apoptosis. The minor ROS dose will react in cell survival while the major ROS dose will trigger apoptosis [14]. Therefore, increase of ROS in E.tapos treated cells caused mitochondrial dysfunction that leads to cancer cell apoptosis by the mitochondrial stress pathway [12].

According to the previous study, E. tapos shell has the highest flavonoid content compared to the E. tapos seed. Among the extraction, the highest amount of flavonoid was found in SHH [15-17]. Flavonoid widely used as cancer chemoprevention and chemotherapy [18]. Coupled with, flavonoid has potential to induce apoptosis in human lung cancer cell [18]. This finding is correlated with extracts that contain flavonoid compound causes apoptosis where occurs morphological changes, increase in ROS activity [19-21].

\section{Conclusions}

All the E. tapos treated group showed the formation of apoptosis. The most effective effects can be seen in SHH treated A549 cells that correlated with apoptosis induction by increasing the ROS activity. Therefore, $\mathrm{SHH}$ is effective for lung cancer treatment via the ROS activation due to the present of highest content of flavonoid.

Author Contributions: S.K.T.: Conceptualization, Methodology, Formal analysis, Writing-Original draft preparation. K.V.P.: Data curation, Writing- draft preparation, N.H.S. and K.K.A.K.: Writing-review and editing, H.B.: Supervision, Validation, Project administration, Funding acquisition. All authors have read and agreed to the published version of the manuscript.

Funding: This project was funded by from Universiti Putra Malaysia (Universiti Putra Malaysia (GPIPM/2016/9470400 and GP-IPS/2018/ 9639700).

Conflicts of Interest: The authors declare no conflict of interest. 


\section{References.}

1. Yong, O.Y.; Salimon, J. Characteristics of Elateriospermum tapos seed oil as a new source of oilseed. Ind. Crop. Prod. 2006, 24, 146-151, doi:10.1016/j.indcrop.2006.03.001.

2. Husin, N.; Tan, N.A.H.; Muhamad, I.I.; Nawi, N.M. Physicochemical and Biochemical Characteristics of the Underutilized Elateriospermum Tapos. J. Teknol. 2013, 64, 57-61, doi:10.11113/jt.v64.2045.

3. Lim, T.K. Elateriospermum tapos. In Edible Medicinal and Non-Medicinal Plants; Springer: Berlin/Heidelberg, Germany, 2012; pp. 472-475.

4. Dandona, P.; Kumar, V.; Aljada, A.; Ghanim, H.; Syed, T.; Hofmayer, D.; Mohanty, P.; Tripathy, D.; Garg, R. Angiotensin II Receptor Blocker Valsartan Suppresses Reactive Oxygen Species Generation in Leukocytes, Nuclear Factor- $\kappa \mathrm{B}$, in Mononuclear Cells of Normal Subjects: Evidence of an Antiinflammatory Action. J. Clin. Endocrinol. Metab. 2003, 88, 4496-4501, doi:10.1210/jc.2002-021836.

5. Perumal, K.V.; Ja'Afar, N.L.; Balan, S.S.; Abidin, A.Z.; Arapoc, D.J.; Shafie, N.H.; Bahari, H. Preventive effect of Elateriospermum tapos seed extract against obese Sprague Dawley rats. Adv. Tradit. Med. 2019, 20, 107-113, doi:10.1007/s13596-019-00394-w.

6. Sita, T.; Thanaset, S.; Prasan, S.; Auamporn, R. Antioxidant and antiproliferative activities of ethanolic extracts of Elateriospermum tapos Blume (Euphorbiaceae). J. Med. Plants Res. 2018, 12, 474-482, doi:10.5897/jmpr2018.6666.

7. Pattamadilok, D.; Suttisri, R. Seco-Terpenoids and Other Constituents fromElateriospermum tapos. J. Nat. Prod. 2008, 71, 292-294, doi:10.1021/np070629g.

8. Attafi, I.M.; Bakheet, S.A.; Korashy, H.M.; AlBakheet, S.A. The role of NF- $\kappa B$ and AhR transcription factors in lead-induced lung toxicity in human lung cancer A549 cells. Toxicol. Mech. Methods 2019, 30, 197-207, doi:10.1080/15376516.2019.1687629.

9. Torre, L.A.; Siegel, R.L.; Jemal, A. Lung Cancer Statistics. Lung Cancer Pers. Med. 2015, 893, 1-19, doi:10.1007/978-3-319-24223-1_1.

10. Homet, B.; Ribas, A. New drug targets in metastatic melanoma. J. Pathol. 2013, 232, 134-141, doi:10.1002/path.4259.

11. Goldstraw, P.; Chansky, K.; Crowley, J.J.; Rami-Porta, R.; Asamura, H.; Eberhardt, W.E.E.; Nicholson, A.G.; Groome, P.; Mitchell, A.; Bolejack, V.; et al. The IASLC Lung Cancer Staging Project: Proposals for Revision of the TNM Stage Groupings in the Forthcoming (Eighth) Edition of the TNM Classification for Lung Cancer. J. Thorac. Oncol. 2016, 11, 39-51, doi:10.1016/j.jtho.2015.09.009.

12. Thiagarajan, S.K.; Arapoc, D.J.; Shafie, N.H.; Yong, Y.K.; Bahari, H.; Adam, Z.; Ei, T. Momordica charantia (Indian and Chinese Bitter Melon) Extracts Inducing Apoptosis in Human Lung Cancer Cell Line A549 via ROS-Mediated Mitochodria Injury. Evid. Based Complement. Altern. Med. 2019, 2019, 2821597-9, doi:10.1155/2019/2821597.

13. Lim, T.K. Edible Medicinal and Non-Medicinal Plants. Fruits. 2012.

14. Redza-Dutordoir, M.; Averill-Bates, D.A. Activation of apoptosis signalling pathways by reactive oxygen species. Biochim. Biophys. Acta (BBA) Bioenerg. 2016, 1863, 2977-2992, doi:10.1016/j.bbamcr.2016.09.012.

15. Ezhilarasan, D.; Shebi, S.; Thomas, J.; Chandrasekaran, N.; Mukherjee, A. Gracilaria foliifera (Forssk.) Børgesen ethanolic extract triggers apoptosis via activation of p53 expression in HepG2 cells. Pharmacogn. Mag. 2019, 15, 259, doi:10.4103/pm.pm_379_18.

16. Li, C.-J.; Tsang, S.-F.; Tsai, C.-H.; Tsai, H.-Y.; Chyuan, J.-H.; Hsu, H.-Y. Momordica charantia Extract Induces Apoptosis in Human Cancer Cells through Caspase- and Mitochondria-Dependent Pathways. Evid. Based Complement. Altern. Med. 2012, 2012, 1-11, doi:10.1155/2012/261971.

17. Nor-Liyana, J.; Siroshini, K.T.; Nurul-Syahirah, M.B.; Chang, W.L.; Nurul-Husna, S.; Daryl, J.A.; Hasnah, B. Phytochemical analysis of Elateriospermum tapos and its inhibitory effects on alpha-amylase, alphaglucosidase and pancreatic lipase. J. Trop. For. Sci. 2019, 31, 240-248.

18. Zhang, H.-W.; Hu, J.-J.; Fu, R.-Q.; Liu, X.; Zhang, Y.-H.; Li, J.; Liu, L.; Li, Y.-N.; Deng, Q.; Luo, Q.-S.; et al. Flavonoids inhibit cell proliferation and induce apoptosis and autophagy through downregulation of PI3K $\gamma$ mediated PI3K/AKT/mTOR/p70S6K/ULK signaling pathway in human breast cancer cells. Sci. Rep. 2018, 8, 1-13, doi:10.1038/s41598-018-29308-7.

19. Badroon, N.A.; Majid, N.A.; Alshawsh, M.A. Antiproliferative and Apoptotic Effects of Cardamonin against Hepatocellular Carcinoma HepG2 Cells. Nutrients 2020, 12, 1757, doi:10.3390/nu12061757.

20. Abotaleb, M.; Samuel, S.M.; Varghese, E.; Varghese, S.; Kubatka, P.; Liskova, A.; Büsselberg, D. Flavonoids in Cancer and Apoptosis. Cancers 2018, 11, 28, doi:10.3390/cancers11010028. 
21. Liu, H.; Jiang, C.; Xiong, C.; Ruan, J. DEDC, a new flavonoid induces apoptosis via a ROS-dependent mechanism in human neuroblastoma SH-SY5Y cells. Toxicol. Vitr. 2012, 26, 16-23, doi:10.1016/j.tiv.2011.10.002.

Publisher's Note: MDPI stays neutral with regard to jurisdictional claims in published maps and institutional affiliations.

(C) 2020 by the authors. Submitted for possible open access publication under the terms and conditions of the Creative Commons Attribution (CC BY) license (http://creativecommons.org/licenses/by/4.0/). 